\title{
Effect of Sulphure Levels on Mustard Crops
}

\author{
Manoj Kumar Singh ${ }^{1}$, Pawan Sirothia ${ }^{1}$, Jitendra Singh ${ }^{2 *}$ and Prasant Kumar Upadhya ${ }^{1}$ \\ ${ }^{1}$ Mahatma Gandhi Chitrakoot Gramoday Vishwavidyalay, Chitrakoot, Satna (M.P.), India \\ ${ }^{2}$ K.V.K, Indore, India \\ *Corresponding author
}

\section{A B S T R A C T}

\section{Keywords \\ Growth parameters, Yield and Yield attributes, \\ Quality parameter and \\ Nutrients uptake \\ Article Info \\ Accepted: 06 September 2018 Available Online: 10 October 2018}

Mustard is second most important edible oilseed crop after groundnut, accounts nearly $30 \%$ of the total oilseeds produced in India. India is one of the largest rapeseed-mustard growing countries in the world, occupying the first rank in area and second in production next to China. Total area under rapeseed and mustard in India is 5.92 million hectares with a production of 6.78 million tonnes and productivity of $1145 \mathrm{~kg} \mathrm{ha}^{-1}$.

\section{Introduction}

Sulphur is the fourth major plant nutrient after nitrogen, phosphorus and potassium for Indian agriculture. It is essential for synthesis of amino acids, proteins, oils, and a component of vitamin $\mathrm{A}$ and activates enzyme system in plant. Three amino acids viz. methionine $(21 \% \mathrm{~S})$, cysteine $(26 \% \mathrm{~S})$ and cystine $(27 \% \mathrm{~S})$ contain $\mathrm{S}$ which are the building blocks of proteins about $90 \%$ of sulphur is present in these amino acids. Sulphur is also involved in the formation of chlorophyll, glucosides and glucosinolates (mustard oils), activation of enzymes and sulphydryl (SH-) linkages that are the source of pungency in oilseeds. Adequate sulphur is therefore very much crucial for oilseed crops.
The literature on sulphure levels on mustard crop has been well documented. In this article effort has been made to review the literature available on Effect of sulphur levels on mustard crops. The effect of sulphur levels on growth character, yield attributes, yield, nutrients uptake, quality characters and economics were presented here.

\section{Growth parameters}

Kumar and Yadav (2007) reported that the plant height increased significantly with each increment in the dose of sulphur up to $15 \mathrm{~kg} \mathrm{~S}$ ha-1. However, the differences in plant height due to further increase in the dose of $S$ were not significant. Application of 30 and $45 \mathrm{~kg} \mathrm{~S}$ ha-1 significantly increased the value of leaf 
area index. An increase in the level of $\mathrm{S}$ significantly improved the dry matter accumulation.

Makeen et al., (2008) reported that the impact of different levels of sulphur on the dry weight of mustard resulted in increase in dry weight with the most favorable response was $60 \mathrm{~kg} \mathrm{~S} \mathrm{ha}^{-1}$. These results are in concurrence with that of (Aulkh et al., 1977).

The higher number of leaves at 90 DAS was obtained form $60 \mathrm{~kg} \mathrm{~S} \mathrm{ha}^{-1}$ and lowest from the control. Number of leaves increased gradually during the different stages of growth $60 \mathrm{~kg} \mathrm{~S} \mathrm{ha}^{-1}$ resulted in best response on leaves after 90 DAS. The number of leaves increased to 104; similarly mustard attained maximum height at $90 \mathrm{DAS}$.

Khatkar et al., (2009) reported that highest plant height and maximum plant dry weight were recorded with higher doses of $\mathrm{S}$ fertilization. Kapur et al., (2010) reported that plant height of mustard was recorded significantly higher with application of $60 \mathrm{~kg}$ $\mathrm{S} \mathrm{ha}^{-1}$ but it was at par with $45 \mathrm{~kg} \mathrm{~S} h a^{-1}$ and $30 \mathrm{~kg} \mathrm{~S} \mathrm{ha}^{-1}$ levels.

Jat et al., (2012) reported that application of $20 \mathrm{~kg} \mathrm{~S}$ ha-1 significantly increased in plant height over control at all the stages of growth except at 30 days after sowing but the highest plant height was observed at $60 \mathrm{~kg} \mathrm{~S} \mathrm{ha}^{-1}$. The results are in agreement with those of Buganova et al., (1975).

Pachauri et al., (2012) reported that various levels of sulphur significantly influenced the growth parameters viz., plant height and dry weight of plant. The plant height increased significantly with each increment in the dose up to $60 \mathrm{~kg} \mathrm{ha}^{-1}$. However, the difference in plant height due to further increase in the dose of sulphur was not significant. Application of $60 \mathrm{~kg} \mathrm{~S} \mathrm{ha}{ }^{-1}$ produced more dry weight of plant at 90 DAS as compared to control and $30 \mathrm{~kg} \mathrm{~S} \mathrm{ha}^{-1}$. Better nutrition to plant resulted in more height and number of branches and other growth parameters, which resulted in higher dry weight of plant. These results are in conformity with those reported by Kumar and Yadav (2007) in mustard.

Sah et al., (2013) reported that application of sulphur resulted into significant variation in the growth characters of mustard. Plant height was significantly improved under $15 \mathrm{~kg} \mathrm{~S} \mathrm{ha}^{-1}$ over control and remained unaffected with further increased up to $45 \mathrm{~kg} \mathrm{~S} \mathrm{ha}^{-1}$.

Contrary to this, highest dose of sulphur i.e. $45 \mathrm{~kg} \mathrm{~S} \mathrm{ha}{ }^{-1}$ produced higher number of functional leaves, branches and dry matter per plant over control. Maximum LAI was produced with $30 \mathrm{~kg} \mathrm{~S} \mathrm{ha}{ }^{-1}$ which was significantly more than $15 \mathrm{~kg} \mathrm{~S} \mathrm{ha}^{-1}$ and control.

Rao et al., (2013) reported that application of sulphur significantly increased the plant height. Addition of sulphur at $45 \mathrm{~kg} \mathrm{ha}^{-1}$ through gypsum recorded the highest plant height. However, it was at par to application of sulphur at $30 \mathrm{~kg} \mathrm{ha}^{-1}$ through elemental sulphur and sulphur bentonite.

Ray et al., (2014) reported that application of sulphur@60 kg S ha ${ }^{-1}$ had significant beneficial effect on various growth parameters of mustard. This treatment was at par with $45 \mathrm{~kg} \mathrm{~S} \mathrm{ha}^{-1}$ for plant height at 75 DAS and at harvest and for LAI at 40 DAS. But there were no significant difference among 30, 45 and $60 \mathrm{~kg} \mathrm{~S}^{-1}$ in increasing the LAI at 75 DAS, dry matter accumulation at 40 and 75 DAS and number of primary branches plant ${ }^{-1}$. Application of $60 \mathrm{~kg} \mathrm{~S} \mathrm{ha}^{-1}$ attained appreciable more crop growth than 20 to $40 \mathrm{~kg} \mathrm{~S} h a^{-1}$. Dry matter production increased with the age of plant and increase was accelerated between 45 and 90 DAS. 


\section{Yield and yield attributes}

Piri and Sharma (2006) reported that seed and straw yield increased significantly with increasing level of sulphur up to highest level of $45 \mathrm{~kg} \mathrm{~S} \mathrm{ha}^{-1}$. Application of 15, 30 and 45 $\mathrm{kg} \mathrm{S} \mathrm{ha}{ }^{-1}$ increased the seed yield over the control by 9,16 and $23 \%$, respectively. All the yield attributes, seeds siliqua ${ }^{-1}, 1000$-seed weight of Indian mustard increased significantly with increasing doses of sulphur up to $45 \mathrm{~kg} \mathrm{ha}^{-1}$, however, the differences between 0 and $15 \mathrm{~kg} \mathrm{~S}^{-1}$ for siliquae plant ${ }^{-1}$ and 1000-seed weight and between 15 and 30 $\mathrm{kg} \mathrm{S} \mathrm{ha}{ }^{-1}$ for seeds siliqua ${ }^{-1}$ and 1000-seed weight were not significant. Jat et al., (2003) also reported an increase in straw yield of Indian mustard with increasing level of sulphur.

Kumar and Yadav (2007) reported that a significant response of crop was observed up to $30 \mathrm{~kg} \mathrm{~S} \mathrm{ha}^{-1}$ in seed and stover yields. Application of $30 \mathrm{~kg} \mathrm{~S}^{-1}$ produced more number of primary branches at 90 days after sowing as compared to control. Number of siliquae/plant significantly increased up to 30 $\mathrm{kg} \mathrm{S} \mathrm{ha}{ }^{-1}$. The highest number of siliquae of $334.2 /$ plant was recorded with $45 \mathrm{~kg} \mathrm{~S} \mathrm{ha}^{-1}$. The highest number of seeds/siliqua was recorded at $45 \mathrm{~kg} \mathrm{~S} \mathrm{ha}^{-1}$, which was on a par with that of $30 \mathrm{~kg} \mathrm{~S} \mathrm{ha}^{-1}$ and was significantly superior to the control and $15 \mathrm{~kg} \mathrm{~S} \mathrm{ha}^{-1}$. The maximum test weight of $4.63 \mathrm{~g} / 1000$ seeds was recorded with $45 \mathrm{~kg} \mathrm{~S} \mathrm{ha}^{-1}$ and minimum in control (3.84 g/1000 seeds).

The seed and stover yields were significantly influenced by different sulphur levels. The highest seed yield and stover yield were recorded at $45 \mathrm{~kg} \mathrm{~S} \mathrm{ha}^{-1}$, which were on a par with those of $30 \mathrm{~kg} \mathrm{~S} \mathrm{ha}^{-1}$ and these were significantly superior to the control. The increase in the seed yield due to application of 15,30 and $45 \mathrm{~kg} \mathrm{~S} \mathrm{ha}^{-1}$ over control was 20.5 , 42.3 and $48.0 \%$, respectively.
Makeen et al., (2008) reported that number of siliqua plant $^{-1}$, number of grains siliquaweight of 1000 seeds, seed yield and harvest index were significantly influenced by application of sulphur. Application of sulphur @ $60 \mathrm{~kg} \mathrm{ha}^{-1}$ recorded the highest values with respect to these parameters. The seed yield increased to $25.5 \mathrm{q} \mathrm{ha}^{-1}$ at $60 \mathrm{~kg} \mathrm{~S}^{-1}$ as compared to $11.1 \mathrm{q} \mathrm{ha}^{-1}$ at control. These results are in agreement with the findings of Raut et al., (2000), Sharma (1994) and Sarma and Dehnath (1999). Harvest index increased significantly and harvest index at $60 \mathrm{~kg} \mathrm{Sha}^{-1}$ was higher than other treatments.

Faujdar et al., (2008) reported that sulphur fertilization at $40 \mathrm{~kg} \mathrm{~S} \mathrm{ha}^{-1}$ remained at par with $60 \mathrm{~kg} \mathrm{~S} \mathrm{ha}^{-1}$ and significantly increased the seed and stover yield to the tune of 26.2 and $12.4 \%$ and 18.5 and $8.5 \%$, respectively over control and $20 \mathrm{~kg} \mathrm{~S} \mathrm{ha}^{-1}$. Similar results have been reported by Singh and Kumar (1996).

Kapur et al., (2010) reported that number of primary and secondary branches plant ${ }^{-1}$, number of siliqua plant $^{-1}$, number of seeds siliqua $^{-1}$ and test weight were recorded significantly higher with $60 \mathrm{~kg} \mathrm{~S}^{-1}$ but it was at par with $45 \mathrm{~kg} \mathrm{Sha}^{-1}$ and $30 \mathrm{~kg} \mathrm{~S} \mathrm{ha}^{-1}$ levels in case of number of primary and secondary branches plant ${ }^{-1}$ as well as found at par with $45 \mathrm{~kg} \mathrm{~S} h a^{-1}$ for number of siliqua plant $^{-1}$, no. of seeds siliqua ${ }^{-1}$ and test weight. The significantly higher seed yield was recorded with sulphur @ $60 \mathrm{~kg} \mathrm{ha}^{-1}$ and higher straw yield was recorded with $\mathrm{S}$ fertilization@45 $\mathrm{kg} \mathrm{ha}^{-1}$ which was at par with $60 \mathrm{~kg} \mathrm{~S}^{-1}$ and $30 \mathrm{~kg} \mathrm{~S} \mathrm{ha}$. The increase in seed yield under $S$ levels at 60, 45, 30 and $15 \mathrm{~kg} \mathrm{ha}^{-1}$ was $45.0,44.9,41.0$ and $23.0 \%$ over control.

Parmar et al., (2010) reported that the significantly highest number of branches per plant and test weight was recorded with $45 \mathrm{~kg}$ 
$\mathrm{S} \mathrm{ha}^{-1}$. However, the control and $15 \mathrm{~kg} \mathrm{~S} \mathrm{ha}^{-1}$ were found at par with each other. These results conformed the findings of Tomar et al., (1996). Application of $45 \mathrm{~kg} \mathrm{~S} \mathrm{ha}{ }^{-1}$ recorded significantly the highest seed yield (20.5 $\left.\mathrm{q} \mathrm{ha}^{-1}\right)$ which was $61.9,26.9$ and $10.0 \%$ higher over control, 15 and $30 \mathrm{~kg} \mathrm{~S} \mathrm{ha}{ }^{-1}$, respectively. The $45 \mathrm{~kg} \mathrm{~S}^{-1}$ recorded 30.8, 17.6 and $3.8 \%$ higher stover yield over control, 15 and $30 \mathrm{~kg} \mathrm{~S} \mathrm{ha}{ }^{-1}$, respectively. However, the 30 and $45 \mathrm{~kg} \mathrm{~S}^{-1}$ levels were statistically at par with each other.

Jyoti et al., (2012) worked at North 24 Parganas, West Bengal on Inceptisol $(\mathrm{pH}$ 6.67) observed that the highest seed and stover yield of rapeseed (cv 'B-9') was 910 and $4320 \mathrm{Kg} \mathrm{ha}^{-1}$, respectively found under the application of $30 \mathrm{Kg} \mathrm{S}^{-1}$ through SSP, resulting in a 41.9 and $18.9 \%$ increase in the yield over that of the control during both of the years.

However, the highest benefit: cost (1.77) was recorded with the foliar application of $1 \% \mathrm{~S}$ 52 (liquid fertilizer) at 20 DAS, vegetative growth stage (35 DAS) and pre flowering stage (50 DAS).

Jat et al., (2012) reported that all the yield attributes (siliquae /plant, seeds /siliqua and test weight), yield (seed and stover) increased significantly with increasing rates of sulphurupto $40 \mathrm{~kg} \mathrm{ha}^{-1}$. But the biological yield increased significantly upto $60 \mathrm{~kg} \mathrm{~S}$ ha

1 . The seed yield increased by 24.8 per cent over no sulphur application. Baudh et al., (2012) reported that productivity increased with increasing level of $\mathrm{S}$. Application of $\mathrm{S}$ was highly influenced with the application of $60 \mathrm{~kg} \mathrm{~S} \mathrm{ha}^{-1}$ than 20 to $40 \mathrm{~kg} \mathrm{~S} \mathrm{ha}^{-1}$. The productivity such as biomass production, number of capsules, seed output and reproductive capacity with grain biological yield also increased with increasing level of S.
Chattopaddhyay and Ghosh (2012) reported that the increase in grain yield was significant in $S$ treated plots over control but higher $S$ level i.e. $60 \mathrm{~kg} \mathrm{~S} \mathrm{ha}^{-1}$ failed to register higher yield increase over that at $45 \mathrm{~kg} \mathrm{~S}^{-1}$. Grain yield of mustard increased significantly with increased levels of S up to $45 \mathrm{~kg} \mathrm{~S}^{-1}$, above which decreasing trend was observed.

Sah et al., (2013) reported that application of sulphur@ $45 \mathrm{~kg} \mathrm{ha}^{-1}$ increased number of siliquae/plant, test weight, seed yield and straw yield. Fertilization of $45 \mathrm{~kg} \mathrm{~S} \mathrm{ha}{ }^{-1}$ produced the highest seed yield of $19.2 \mathrm{q} \mathrm{ha}^{-1}$ in comparison to $13.2 \mathrm{q} \mathrm{ha}^{-1}$ in control. Rao et al., (2013) reported that sulphur application significantly influenced the yield attributing characters and yield over control regardless of the levels of sulphur.

Debnath et al., (2014) reported from Kalyani (West Bengal) that the seed yield on average was $14.5 \%$ higher in elemental $\mathrm{S}$ over the control which further increased to $30.6 \%$ along with inoculated S oxidizers.

Neha et al., (2014) reported that application of $40 \mathrm{~kg} \mathrm{~S} \mathrm{ha}^{-1}$ recorded significantly higher seed yield (19.6 q ha $\left.{ }^{-1}\right)$ and stover yield (70.9 $\mathrm{q} \mathrm{ha}^{-1}$ ) over $20 \mathrm{~kg} \mathrm{~S} \mathrm{ha}{ }^{-1}$ and no sulphur higher to this level remained at par with each other. Application of $40 \mathrm{~kg} \mathrm{~S} \mathrm{ha}{ }^{-1}$ gave significantly higher seed and stover yield by registering 12.9 and $13.5 \%$ higher over no sulphur. Further, increase in sulphur levels up to $60 \mathrm{~kg} \mathrm{~S} \mathrm{ha}^{-1}$ remained at par with above level. Ray et al., (2014) reported that yield of mustard was increased with the increasing dose of $\mathrm{S}$ from 0 to $60 \mathrm{~kg} \mathrm{ha}^{-1}$. Higher yield was obtained with $60 \mathrm{~kg} \mathrm{~S} \mathrm{ha}^{-1}$ resulting in $17.9 \%$ increase over control. Singh and Kumar (2014) reported that application of 120 $\mathrm{kg} \mathrm{N} \mathrm{ha}{ }^{-1}$ and $45 \mathrm{~kg} \mathrm{~S} \mathrm{ha}^{-1}$ was the best combination for getting higher seed yield, siliquae plant $^{-1}$, siliquae length, number of seed siliquae ${ }^{-1}$ and harvest index. 


\section{Quality parameter}

\section{Oil content}

Abdin et al., (2003) observed that the protein content in the seed of mustard can be optimized with the split application of $40 \mathrm{~kg} \mathrm{~S}$ $\mathrm{ha}^{-1}$ during the appropriate phenological stages of crop growth and development.

Chandel et al., (2003) reported that the application of $40 \mathrm{~kg} \mathrm{Sha}^{-1}$ to mustard resulted in significant increase in oil yield of mustard.

Singh and Mukherjee (2004) reported that oil yield of mustard increased with increasing dose of sulphur from 0 to $45 \mathrm{~kg} \mathrm{~S} \mathrm{ha}{ }^{-1}$. However, Sharma et al., (2005).reported that the oil content in mustard increased up to 32.5 $\mathrm{kg} \mathrm{Sha}{ }^{-1}$.

Singh et al., (2005) also observed that the oil content in mustard seed significantly increased $6.3 \%$ with $60 \mathrm{~kg} \mathrm{~S}^{-1}$ over no sulphur application. Piri and Sharma (2006) reported that oil content of mustard increased significantly with increasing level of sulphur up to highest level of $45 \mathrm{~kg} \mathrm{~S} \mathrm{ha}^{-1}$. Application of 15,30 and $45 \mathrm{~kg} \mathrm{~S} \mathrm{ha}{ }^{-1}$ increased the oil content by 13, 22 and 33\%, respectively.

Mehdi et al., (2006) conducted a field experiment with 4 levels of sulphur 20, 40, 60 and $80 \mathrm{~kg} \mathrm{ha}^{-1}$ and reported that oil content in seed of mustard increased with increasing rate of sulphur.

Singh and Singh (2007) reported that each successive increase in the level of sulphur up to $60 \mathrm{~kg} \mathrm{ha}^{-1}$ significantly increased the oil content of the crop by $36.7 \%$ over control.

Singh et al., (2008) reported from Kanpur that the application of $90 \mathrm{~kg} \mathrm{~N}$ and $30 \mathrm{~kg} \mathrm{~S}^{-1}$ significantly increased the seed, oil and protein yields, and protein content of seed. The uptake of both $\mathrm{N}$ and $\mathrm{S}$ by seeds increased with increasing levels of each of the nutrient. Higher doses of $\mathrm{N}$ decreased the oil percentage in seed whereas sulphur up to 40 $\mathrm{kg} \mathrm{ha}^{-1}$ significantly increased it.

Singh et al., (2010) reported that protein content increased with increasing fertility levels and recorded the highest value at 150 $\%$ RDF.

Basumatary and Talukdar (2011) observed at, Jorhat, Assam that the highest oil content $(41.3 \%)$ was obtained due to integration of 60 $\mathrm{kg}$ of S with $3.0 \mathrm{t} \mathrm{FYM} \mathrm{ha}^{-1}$ and resulted in a $12.8 \%$ increase in oil content over the control.

Najar et al., (2011) worked at Wadura (Jammu \& Kashmir) on clay loam soil and found that the protein content in soybean seeds increased from 34.17 to 37.39 per cent with the increasing levels of sulphur and 35.41 to 36.34 per cent with the increasing levels of boron which was 9.42 and 2.63 per cent higher respectively over the control.

Kumar and Trivedi (2012) reported that the oil content increased significantly with increasing level of sulphur up to highest level of $60 \mathrm{~kg} \mathrm{~S} \mathrm{ha} a^{-1}$. Application of $60 \mathrm{~kg} \mathrm{~S} h a^{-1}$ increased the oil content by 7.8, 4.8 and $3.9 \%$ over 0,20 and $40 \mathrm{~kg} \mathrm{~S}$ ha $^{-1}$, respectively. Pachauri et al., (2012) reported that the oil content recorded less than $90 \mathrm{~kg} \mathrm{~S}^{-1}$ were higher by $11.3,7.4$ and 1.5 per cent over 0,30 and $60 \mathrm{~kg} \mathrm{~S} \mathrm{ha}^{-1}$, respectively.

Sah et al., (2013) reported that application of sulphur@ $45 \mathrm{~kg} \mathrm{ha}^{-1}$ increased the oil content of mustard. Neha et al., (2014) reported that an application of $40 \mathrm{~kg} \mathrm{~S} h a^{-1}$ significantly enhanced the oil content by 5.0 and $8.7 \%$ in comparison to $20 \mathrm{~kg} \mathrm{~S} \mathrm{ha}^{-1}$ and no sulphur. Singh and Kumar (2014) reported that the application of $120 \mathrm{~kg} \mathrm{~N}$ and $45 \mathrm{~kg} \mathrm{~S} \mathrm{ha}^{-1}$ was 
the best combination for getting higher oil content in seed of mustard.

\section{Protein content}

Singh and Singh (2005) reported that with the increasing dose of sulphur significantly increased the protein content in seed of mustard.

Mehdi et al., (2006) reported that protein yield increased with increasing rate of sulphur, whereas protein content in seed of mustard was increased with increasing rate of sulphur up to $60 \mathrm{~kg} \mathrm{ha}^{-1}$ only and it was decreased their after. Kumar and Yadav (2007) reported from Faizabad that the application of $90 \mathrm{~kg} \mathrm{~N}$ and $30 \mathrm{~kg} \mathrm{~S} \mathrm{ha}^{-1}$ significantly increased the seed, oil and protein yields, and protein content of seed.

Bhat et al., (2007) studied at Rajouri (Jammu \& Kashmir), and found that protein content $(23.88 \%)$ and oil content $(42.90 \%)$ in mustard seed were registered higher with the application of $25 \%$ FYM N $+75 \%$ fertilizer $\mathrm{N}$ $+40 \mathrm{~kg} \mathrm{~S} \mathrm{ha}{ }^{-1}$ and 50\% FYM-N $+50 \%$ fertilizer $\mathrm{N}+40 \mathrm{~kg} \mathrm{~S} \mathrm{ha}{ }^{-1}$ statistically identical to each other and significant difference to the rest of the treatments. Singh et al., (2008) reported from Kanpur that the application of $90 \mathrm{~kg} \mathrm{~N}$ and $30 \mathrm{~kg} \mathrm{~S} \mathrm{ha}$ significantly increased the seed, oil and protein yields, and protein content of seed. The uptake of both $\mathrm{N}$ and $\mathrm{S}$ by seeds increased with increasing levels of each of the nutrient. Higher doses of $\mathrm{N}$ decreased the oil percentage in seed where assulphur up to 40 $\mathrm{kg} \mathrm{ha}^{-1}$ significantly increased it.

Singh et al., (2010) reported that protein content increased with increasing fertility levels and recorded the highest value at 150 $\%$ RDF.

Najar et al., (2011) worked at Wadura (Jammu \& Kashmir) on clay loam soil and found that the protein content in soybean seeds increased from 34.17 to 37.39 per cent with the increasing levels of sulphur and 35.41 to 36.34 per cent with the increasing levels of boron which was 9.42 and 2.63 per cent higher respectively over the control.

Kumar and Trivedi (2011) reported from Gwalior M.P that the application of $60 \mathrm{~kg} \mathrm{~S}$ $\mathrm{ha}^{-1}$ increased the oil content by $7.84,4.87$ and $3.93 \%$ over 0,20 and $40 \mathrm{~kg} \mathrm{~S} \mathrm{ha}{ }^{-1}$ respectively. The highest seed protein $(23.86 \%)$ was recorded due to application of $60 \mathrm{~kg} \mathrm{~S} \mathrm{ha}{ }^{-1}$ and decreasing levels of S led to significant decreasing in this bio-chemicals parameter of mustard. Among different sources of sulphur, the highest protein content $(22.43 \%)$ was observed due to ammonium sulphate followed by pyrite (21.59\%), gypsum (21.29\%) and SSP (20.86\%), respectively.

\section{Nutrient concentration in soil and uptake}

Lanjewar et al., (2005) reported that it was found that increasing application of sulphur significantly increased the nutrient uptake and content of $\mathrm{S}$ upto $60 \mathrm{~kg} \mathrm{~S} \mathrm{ha}{ }^{-1}$. However, 60 $\mathrm{kg} \mathrm{S} \mathrm{ha}{ }^{-1}$ was better than $20 \mathrm{~kg} \mathrm{~S} \mathrm{ha}^{-1}$ in these respects. Thus $60 \mathrm{~kg} \mathrm{~S}$ followed by $40 \mathrm{~kg} \mathrm{~S}$ ha $^{-1}$ appeared to be appropriate doses to increase the uptake.

Piri and Sharma (2006) reported that $30 \mathrm{~kg} \mathrm{~S}$ $\mathrm{ha}^{-1}$, being at par with $15 \mathrm{~kg} \mathrm{~S} \mathrm{ha}$, significantly increased sulphur content in seed over no sulphur, whereas sulphur content increased with increasing dose of sulphur up to $30 \mathrm{~kg} \mathrm{~S} \mathrm{ha}^{-1}$. Further increase in the dose of sulphur from 30 to $45 \mathrm{~kg} \mathrm{~S} \mathrm{ha}^{-1}$ did not increase sulphur content in seed further.

Singh and Singh (2007) reported that the S content in seed increased significantly with increasing levels of $S$ up to $60 \mathrm{~kg} \mathrm{ha}^{-1}$. Application of $\mathrm{S}$ increased its content in seeds 
from $0.40 \%$ in control to $0.49 \%$ with $60 \mathrm{~kg} \mathrm{~S}$ $\mathrm{ha}^{-1}$. Kumar and Yadav (2007) reported that uptake of $S$ increased with increase in the level of S. Further increase in the dose of $S$ did not result in significant increase in $S$ uptake by the crop. However, the differences were statistically significant only up to $30 \mathrm{~kg}$ $\mathrm{S} \mathrm{ha}^{-1}$. Application of $\mathrm{S}$ also resulted in significant increase in the $\mathrm{S}$ uptake over the control only. Its application at $45 \mathrm{~kg} \mathrm{~S} \mathrm{ha}^{-1}$ also showed significant $\mathrm{S}$ uptake over that of $15 \mathrm{~kg} \mathrm{~S} \mathrm{ha}^{-1}$.

Zizale et al., (2008) reported that the total uptake of $\mathrm{S}$ increased significantly with increase in each dose of $\mathrm{S}$ up to $45 \mathrm{~kg} \mathrm{ha}^{-1}$. The per cent increase in total $\mathrm{S}$ uptake was 11.2 and 66.0 over control with application of $\mathrm{S}$ at 15,30 and $45 \mathrm{~kg} \mathrm{ha}^{-1}$, respectively. The maximum $\mathrm{S}$ uptake $\left(34.5 \mathrm{~kg} \mathrm{ha}^{-1}\right)$ was recorded with $45 \mathrm{~kg} \mathrm{~S} \mathrm{ha-1}$. The highest $\mathrm{S}$ content in seed was recorded under the highest dose of $\mathrm{S}$ at $45 \mathrm{~kg} \mathrm{ha}^{-1}$, which was significantly superior to the rest of the treatments. The similar trend was found for $\mathrm{S}$ content of straw. The maximum value of $0.49 \%$ and $0.40 \%$, respectively was recorded for seed and straw at the highest level of $S$ at $45 \mathrm{~kg} \mathrm{ha}^{-1}$. The maximum $\mathrm{S}$ uptake by seed was recorded at $\mathrm{S} 45$, which was on par with S30 level but significantly superior to rest of the levels.

Yadav et al., (2010) reported that the slight decrease in $\mathrm{pH}$ and $\mathrm{EC}$ and increase in organic carbon, available nitrogen, phosphorus, potassium and sulphur after harvest of mustard was recorded by application of sulphur @ $40 \mathrm{~kg} \mathrm{ha}^{-1}$. Gangwar et al., (2011) conducted a field experiment and found that different levels of sulphur significantly improved the growth, yield as well as uptake of nutrients by seeds and straw of mustard. Seed inoculation with PSB significantly increased yield, uptake by seed and straw and availability of nutrients in soil.
Combined effect of $50 \mathrm{~kg} \mathrm{P} 2 \mathrm{O} 5$ and $40 \mathrm{~kg} \mathrm{~S}$ $\mathrm{ha}^{-1}$ with seed inoculation with PSB gave higher seed and straw yield as well as nutrient content in seed and straw which resulted in higher nutrient uptake by mustard grown in loamy sand of North Gujarat.

Chattopaddhyay and Ghosh (2012) reported that $\mathrm{S}$ concentration in grain and stover of mustard increased significantly with increasing $S$ levels up to $60 \mathrm{~kg} \mathrm{~S} \mathrm{ha}{ }^{-1}$, irrespective of sources of $\mathrm{S}$. Results indicated that the crop responded to $S$ application since soil was deficient in available $S$. $S$ concentration in mustard grain and stover due to graded levels of $\mathrm{S}$ ranged from 0.69 to 0.89 and 0.18 to 0.36 per cent, respectively. Total $S$ uptake continued to increase with the increase in levels of $S$ irrespective of its source.

Neha et al., (2014) reported that application of $60 \mathrm{~kg} \mathrm{~S} \mathrm{ha}^{-1}$ improved concentration of $\mathrm{S}$ in seed and stover. Similarly, application of 40 $\mathrm{kg} \mathrm{S} \mathrm{ha}{ }^{-1}$ recorded 13.6 and $38.2 \%$ of $\mathrm{S}$ over $20 \mathrm{~kg} \mathrm{~S} \mathrm{ha-1}$ and no sulphur, respectively. However, the further increase in sulphur level was statistically at par with this level. The results are in close conformity with findings of Abraham (2001) and Patel et al., (2009).

\section{Economics}

Singh and Singh (2007) reported that net returns increased with the increase in $\mathrm{S}$ dose up to $60 \mathrm{~kg} \mathrm{ha}^{-1}$ and this dose resulted in the highest net returns. The benefit: cost ratio in sulphur fertilizer was $1.75,1.84$ and 1.96 due to application of 20,40 and $60 \mathrm{~kg} \mathrm{~S} \mathrm{ha}{ }^{-1}$, respectively. Malviya et al., (2007) reported that sulphur application at $60 \mathrm{~kg} \mathrm{~S} \mathrm{ha}^{-1}$ was found remunerative by Rs. $483 \mathrm{ha}^{-1}$ over 30 $\mathrm{kg} \mathrm{S} \mathrm{ha}^{-1}$.

Kumar and Trivedi (2012) reported that the net return (Rs. 25098 ha $^{-1}$ ) and benefit: cost 
ratio (3.73) was recorded at $40 \mathrm{~kg} \mathrm{~S} \mathrm{ha}^{-1}$. This may be because of the difference in yield between 40 and $60 \mathrm{~kg} \mathrm{~S}^{-1}$ was at par and cost of cultivation was lesser with $40 \mathrm{~kg} \mathrm{~S}$ ha $^{-1}$. Pachauri et al., (2012) reported that the highest net return of Rs. 42, 018 was recorded with the application of $90 \mathrm{~kg} \mathrm{~S}^{-1}$. However, B: C ratio of 4.34 was higher at $60 \mathrm{~kg} \mathrm{~S} \mathrm{ha}^{-1}$. Whereas $90 \mathrm{~kg} \mathrm{~S}^{-1}$ gave 4.25 followed by $30 \mathrm{~kg} \mathrm{~S} \mathrm{ha}^{-1}$ (4.06) and control plot (4.04).

Verma et al., (2012) conducted a field experiment during rabi season of 2008-09 and $2009^{-1} 0$ at Kanpur to evaluate the effect of sulphur $\left(0,20,40\right.$ and $\left.60 \mathrm{~kg} \mathrm{~S} \mathrm{ha}^{-1}\right)$, zinc $(0,5$ and $\left.10 \mathrm{~kg} \mathrm{Zn} \mathrm{ha}^{-1}\right)$ and boron (0, 0.5 and 1.0 $\mathrm{kg} \mathrm{B} \mathrm{ha}{ }^{-1}$ ) levels on quality, economics and uptake of nutrients by mustard [Brassica juncea (L.)]. On economic basis, the highest profit was recorded with combined use of 60 $\mathrm{kg} \mathrm{S}+5 \mathrm{~kg} \mathrm{Zn}$ and $1.0 \mathrm{~kg} \mathrm{~B} \mathrm{ha}^{-1}$.

Sah et al., (2013) reported that application of $45 \mathrm{~kg} \mathrm{~S} \mathrm{ha}{ }^{-1}$ gave maximum net return (Rs. $25599 \mathrm{ha}^{-1}$ ) which was followed by $30 \mathrm{~kg} \mathrm{~S}$ $\mathrm{ha}^{-1}\left(23365 \mathrm{ha}^{-1}\right.$ ) and $15 \mathrm{~kg} \mathrm{~S} \mathrm{ha}^{-1}$ (Rs. 19221 $\mathrm{ha}^{-1}$ ) and gave highest maximum $\mathrm{B}$ : $\mathrm{C}$ ratio of 3.89 .

Verma et al., (2012) reported that the application of $60 \mathrm{~kg} \mathrm{~S}^{-1}$ gave significantly higher protein content $(\%)$ in seed.

\section{References}

Abdin, M.Z. Khan, N. Khan, I. Issar, M. and Jamal, A., "Nitrogen and sulphur interaction in relation to yield and quality attributes of rapeseed mustard". Brassica, 5(3/4): 35-41, 2003.

Basumatary, A. and M.C. Talukdar, "Integrated Effect of Sulphur and Farmyard Manure on Yield, Quality of Crops and Nutrient Status under Rapeseed-Rice Cropping System in Fluventic Dystrochrept". Journal of the Indian Society of Soil Science, 59, 4, 397-400, 2011.
Bhat, Mohd. Auyoub, Singh, Room and Kohli, Anshuman, "Effect of Integrated Use of Farmyard Manure and Fertilizer Nitrogen with and without Sulphur on Yield and Quality of Indian Mustard (Brassica juncea L.)". Journal of the Indian Society of Soil Science, 55, 2, 224-226, 2007.

Chandel, R.S. Sudhakar, P.C. and Singh, Kalyan, "Direct and residual effect of sulphur on Indian mustard (Brassica juncesa) in rice (Oryza sativa) Indian mustard cropping system". Indian Journal of Agricultural Sciences, 74 (4): 230-232, 2003.

Chattopaddhyay, S. and Ghosh, G. K. Response of rapeseed (Brassica juncea L.) to various sources and levels of sulphur in red and lateritic soils of West Bengal, India. International Journal of Plant, Animal and Environmental Sciences 2(4): 50-59, 2012.

Debnath Abhijit, Subhas Chandra, kole and Joseph, M. Sukhim., "Evaluation of the efficacy of different sulphur amendments and sulphur oxidizing bacteria in relation to its transformation in soil and yield of mustard (Brassica juncea)". Research on Crops, 15 (3): 578-584, 2014.

Faujdar, R.S., Mathur, A.K. and Verma, A.K. "Yield and quality of mustard as influenced by different levels of phosphorus and sulphur". An Asian Journal of Soil Science 3 (1): 207-208, 2008

Gangwar, T.V., Patel, M.V. and Jadav, N.J. "Effect of phosphorus, sulphur and phosphate solubilizing bacteria on yield, nutrient uptake and soil fertility after harvest of mustard". Indian Journal of Fertilizers, 7(8):32-40, 2011.

Jat, J.S., Rathore, B.S. and Chaudhary, M.G. Effect of sulphur and zinc on growth, chlorophyll content, yield attributes and yields of mustard (Brassica juncea) on clay loam soil of Rajasthan. AGRES- An International e-Journal 1 (1): 42-52, 2012.

Jyoti, Kumari, NaikSushanta Kumar, Mandal Mitali and Das Dilip Kumar. "Performance of different Sources of 
Sulphur on the Yield and Quality of Rapeseed (Brassica campestris L.)". Journal of the Indian Society of Soil Science, 60, 3, 218-224, 2012.

Kapur, L.T., Patel, A.R. and Thakor, R.F. Yield attributes and yield of mustard (Brassica juncea L. Czern and Coss) as affected by sulphurlevels. An Asian Journal of Soil Science 5 (1): 216-2172010.

Khatkar, Y., Dawson, J., Kishanrao,Z. K., Dixit, P.M. and Khatkar, R. Effect ofnitrogen, phosphorus and sulphur fertilization on growth and yield of mustard (Brassica junceaCoss).International Journal of Agricultural Sciences 5(2):396-398, 2009.

Kumar, H. and Yadav, D.S. Effect of phosphorus and sulphur levels on growth, yield and quality of Indian mustard (Brassica juncea) cultivars. Indian Journal of Agronomy 52 (2): 154-157, 2007.

Kumar, R. and Trivedi, S.K., "Effect of levels and sources of sulphur on yield quality and nutrient uptake by mustard" Progressive Agriculture, 12 (1): 69-73, 2012.

Lanjewar, A.D. and Selukar, S. S. Effect of phosphorus and sulphur application onnutrient uptake of mustard (Brassica juncea L.) Journal of Soils and Crops 15 (2):433-436, 2005.

Makeen, K., Kumari, A., Chaurasia, A.K. and Hakeem, S. Effect of different levels of sulphur application on physiological and the yield behavior of mustard (Brassica juncea L.). Progressive Research, 3 (1): 53-56, 2008.

Mehdi, S.S. Singh, O.P. and Singh, P., "Influence of sulphur fertilization on various quality characters on Indian mustard (Brassica juncea L.) in the North Western tract of Uttar Pradesh". Environment and Ecology, 24 (2): 338340, 2006.

Najar, G. R. Farida Akhtar, Seerat un Nisa, K. R. Dar, and. Peer, F. A. "Effect of sulphur and boron interaction on yield, nutrient uptake and quality characters of soya bean (Glycine max) and sunflower and $B$. juncea under temperate conditions". Journal of Research, SKUAST-J, 10, 2, 41- 49, 2011.

Neha, Dashora, L. N. Kaushik, M. K. and Upadhyay, B. "Yield, nutrient content, uptake and quality of Indian mustard genotypes as influenced by sulphur under Southern Rajasthan conditions". Annals of Agriculture and Biological Research, 19(1): 81-84, 2014.

Pachauri, R. K. Trivedi, S. K. Kumar, Y., "Effect of sulphur levels on growth, yield and quality of Indian mustard genotypes and their economics". Journal of Soils and Crops, 22(2): 258-263, 2012.

Parmar, R.M., Parmar, J.K. and Patel, M.K. Effect of nitrogen and sulphur on yield and yield attributes of mustard under the loamy sand soil of North Gujarat. An Asian Journal of Soil Science 5 (2): 295299, 2010.

PIRI, ISSA, and Sharma, S.N. "Physiological analysis of growth and yield of Indian mustard as affected by irrigation and sulphur" Indian Journal of Plant Physiology, 11(3): 253-260, 2006.

Rao, K. T., Rao, A. U. and Sekhar, D. Effect of sources and levels of sulphur on groundnut. Journal of Academia and Industrial Research, Vol 2 (5): 268-270, 2013.

Ray, K., Pal, A.K., Banerjee, H. and Phonglosa, A. 2014. Correlation and path analysis studies for growth and yield contributing traits in Indian mustard (Brassica juncea L.). International Journal of Bio-resource and Stress Management, 5(2): 200-206.

Sah, D., Sewak, R., Singh, A.K. and Swami, S. Growth, yield and profitability of Indian mustard (Brassica juncea (L.) Czern \& Coss) with different weed control measures and sulphur levels. Agricultural Science Digest 33 (1): 15-20, 2013.

Singh, A.K. Singh, S.N. Singh, O. P. and Khan, M. A., "Quality of indian mustard (Brassica juncea L.) as Affected by Nitrogen and Sulphur Fertilizers in a Nutrient Deficient Soil”. Indian Journal of 
Agricultural Biochemistry, 21 (1 \& 2), 39-41, 2008.

Singh, M. and Kumar, M., "Effect of nitrogen and sulphur levels on seed yield and some other characters in mustard (Brassica juncea L.)". International Journal of Agricultural. Sciences, 10(1): 449-452, 2014.

Singh, R. and Singh, V., "Effect of sulphur on growth and yield of Indian mustard under saline condition". Indian Journal of Agronomy, 50 (2): 110-113, 2005.

Singh, R.B. and Dhiman, O.P., "Effect of sulphur and zinc on Indian mustard (Brassica juncea)". Indian Journal of Agricultural Sciences, 75 (14): 826-829, 2005.

Singh, R.K. and Mukharjee, D., "Effect of sulphur fertilization in sustaining mustard productivity in rice mustard cropping system". Haryana Journal of Agronomy, 20 (1/2): 7-9, 2004

Singh, R.K. Singh, A.K. and Kumar, R., "Effect of fertility levels on nutrient uptake, yield and quality of Indian Mustard (Brassica juncea) varieties under late sown condition". Environment and Ecology, 38 (3A): 1764-1767, 2010.

Singh, Rajesh Kumar, Singh Y, Singh Amitesh Kumar, Kumar Rakesh, and Rakesh V.K., "Productivity and economics of mustard
(Brassica juncea) varieties as influenced by different fertility levels under late sown condition". Indian Journal of Soil Conservation, 38, 2, 121-124, 2010

Singh, S. and Singh, V. Effect of sources and levels of sulphur on yield, quality and nutrient uptake by linseed (Linum usitatissimum). Indian Journal of Agronomy 52 (2): 158-159, 2007.

Verma, C. K. Prasad, K. and Yadav, D. D., "Studies on response of sulphur, zinc and boron levels on yield, economics and nutrients uptake of mustard (Brassica juncea L.)". Crop Research, 44(1/2):7578, 2012.

Yadav, H.K., Thomas, T. and Khajuria, V. Effect of different levels of sulphur and biofertilizer on the yield of Indian mustard (Brassica juncea L.) and soil properties. Journal of Agricultural Physics 10: 61-65, 2010.

Zizala, V.J. Jadav, N.B., Gorfad, P.S., "Effect of sulphur and zinc on yield, quality and its concentration on mustard". Asian Journal, 3, (1): 173-177, 2008.

Zizale, V.J., Jadav, N.B. and Gorphrfed, P.S. Effect of sulphur and zinc on yield, quality and its concentration on mustard. An Asian Journal of Soil Science Vol3 (1): 173-177, 2008.

\section{How to cite this article:}

Manoj Kumar Singh, Pawan Sirothia, Jitendra Singh and Prasant Kumar Upadhya. 2018. Effect of Sulphure Levels on Mustard Crops. Int.J.Curr.Microbiol.App.Sci. 7(10): 481-490. doi: https://doi.org/10.20546/ijcmas.2018.710.052 